\title{
Instantiation of Organisational Routines in Cross-Expertise Collaborative Enterprise Systems
}

\author{
Nicholas Dacre ${ }^{a^{*}}$, Panos Constantinides ${ }^{a}, \&$ Joe Nandhakumar \\ ${ }^{a}$ University of Warwick Business School, University of Warwick, Coventry, CV4 7AL, UK \\ ${ }^{*}$ Corresponding Author: nicholas.dacre@mail.wbs.ac.uk
}

\begin{abstract}
This study aims to explore the dynamics between the performative and ostensive aspects of organisational routines in the context of cross-expertise collaborative enterprise systems. Specifically, through an ongoing empirical case study of technology, media and communication businesses focusing on social and mobile systems, we will explore cross-expertise collaborative enterprise systems routines and how those influence, and are guided by the concept of gamification.

Keywords: Gamification, Organisational Routines, Enterprise Systems, Process Research, CrossExpertise, Collaborative Systems.

\footnotetext{
Citation

Dacre, N., Constantinides, P., \& Nandhakumar, J. (2014). Instantiation of Organisational Routines in Cross-Expertise Collaborative Enterprise Systems. International Symposium on Process Organization Studies, Rhodes, Greece. https://dx.doi.org/10.2139/ssrn.3829127
}

\section{Introduction}

Organisational routines have been historically conceptualised as loosely coupled, but repetitive, performance programmes that allow organisations to react to the environment (March \& Simon, 1958). Feldman (2000) and later Feldman and Pentland (2003) challenged this understanding by proposing that routines can change continuously, opening the routines' black box to analyse the interactions between different aspects of routines as those are performed over time (Zbaracki \& Bergen, 2010; Parmiggiani \& HowardGrenville 2011; Rerup \& Feldman, 2011; Turner \& Rindova, 2012).

This renewed understanding has shifted the emphasis from a characterisation of routines as undifferentiated monolithic 'objects' to generative, continuously emerging, processes. Work in this tradition explores the mutual constitution of routines through two aspects; the ostensive aspect, which is the "abstract, generalised idea of the routine" and the performative aspect, which consists of "specific actions, by specific people, in specific places and times" (Feldman \& Pentland, 2003: 101).

Much work remains to be done in tracing how the ostensive and performative aspects of a routine interrelate over time and space to shed light on how micro processes guide more macro level conceptions of organisational routines. 


\section{Research Premise}

Collaboration and cross-expertise actor engagement are increasingly key components for the application of contemporary, web-based digital systems (Kellogg et al., 2006; Panourgias, Nandhakumar, \& Scarbrough, 2013). In contrast to legacy enterprise systems, applications such as Yammer, WebEx Social, Confluence, Facebook, LinkedIn, FourSquare, and Foldit appeal to various users through the implementation of engaging content (Ellison et al., 2007; Skeels \& Grudin, 2009; Khatib et al., 2011; Lindqvist et al., 2011; Noulas et al., 2011; Zichermann \& Cunningham, 2011; Riemer et al., 2012).

Organisations face their most difficult challenges in the application of these contemporary digital systems as actors instantiate organisational routines that cross expert boundaries. Thus, in this paper we explore the dynamics between the performative and ostensive aspects of organisational routines in the context of cross-expertise collaborative enterprise systems. Specifically, through our empirical case study of technology, media and communication businesses focusing on social and mobile systems, we will explore crossexpertise collaborative enterprise systems routines and how those influence, and are guided by the concept of gamification (Deterding et al. 2011, Thom et al. 2012).

Gamification is the use of game processes in online non-game contexts to engage users in a collaborative manner with participants provided with rewards for accomplishing desired tasks (Thom et al., 2012). Through extrinsic and intrinsic motivational factors, types of rewards can include points, achievements, badges, levelling-up and wider recognition (Werbach and Hunter, 2012). We conceptualise such gamification processes in our empirical case study as performative instantiations of ostensive cross-expertise collaborative routines.

\section{Empirical Insights}

In one example from an ongoing empirical case, Alexia, a high-ranking account manager based in Canada with a wealth of experience in dealing with large corporate clients, and Simon, a newly appointed systems analyst graduate based in the UK having recently completed the internal company training programme, developed and collaborated on a joint campaign for the first time.

The process took place through a bespoke company-wide global operating system styled as a Massively Multiplayer Online Game (MMOG). Alexia was ranked as the top 'player' within the system out of circa 3,000 worldwide employees, with a prominent online profile and a list of achievements and points on the internal leaderboard system. Simon having recently joined the company was keen to prove his worth and had accumulated several awards in a relatively short time in recognition of his achievements.

Using the system both Alexia and Simon were able to determine each other's knowledge areas and expertise, and how they could collaborate. For example, they were able to recognise what knowledge each award and past campaigns represented and how these could complement their joint work online.

The MMOG styled enterprise system not only encouraged collaborative processes and enacted dynamic routines, but also was noted to create friction amongst high-ranking participants and barriers of participation amongst large disparity members on the internal achievements and leaderboard rankings. 
This example demonstrates how by enacting those gamified design processes, Alexia and Simon instantiated organisational routines that are often taken for granted in enterprise systems. As the Chief Operations Officer explained to us in an interview, gamification provides the "reason" or what we call a platform for instantiating organisational routines:

"The people I work with are around me - I might be in a different location but there are ways and means of us communicating and there's no real push for me to go and post a comment or share some information on any of these things. You kind of need a reason to collaborate. So, part of the game mechanic is providing that reason within the system"

In this sense, gamified enterprise processes open the black box of organisational routines to enable an analysis of the interactions between different actors as those are performed over time. We provide details of the dynamics between micro instantiations and macro cross-expertise collaborative enterprise systems routines and explore implications for theory.

\section{Discussion and Further Research}

First, through ongoing analysis of gamified collaborative processes as those are implicated in taken for granted organisational routines, we will illustrate both the emergence and generativity of routines (Feldman and Pentland 2003; Rerup \& Feldman, 2011).

Specifically, we will examine how ostensive cross-expertise collaborative enterprise systems routines such as, developing and joining a campaign, selecting a team, assessing team members skills and knowledge, and assigning them to individual design tasks, become explicitly instantiated (or "invoked" to use Feldman and Pentland's (2003) language) on the online platform through the gamified collaborative processes.

Through these explicit instantiations (e.g. selecting based on previous achievements, rewards, points and rankings) we will digitally trace the emergence of collaborative enterprise routines (i.e. how they are performed) and their generativity (i.e. how they sustain or change the ostensive aspect of those routines).

Second, we will explore the implications of our empirical findings for better understanding the processes that shape cross-expertise collaboration through gamified enterprise processes (Gal et al 2008; Levina \& Vaast, 2008; Barrett \& Oborn, 2010).

Previous work has argued that beyond studying how diverse technologies serve as an occasion for social reorganisation, research also needs to pay attention at the materiality of technology and how it can reconfigure work boundaries and relations of practice (Barrett et al 2012).

This research will therefore contribute to this literature by examining how gamified enterprise processes mediate boundary relations between actors through their direct impact on those actors' status (e.g. their points and achievements) and social control (e.g. through their followers and digital feedback mechanisms).

Finally, we will consider the implications of instantiating ostensive cross-expertise routines for understanding challenges of collaborative enterprise systems through contemporary digital systems. 


\section{References}

Barrett, M., \& Oborn, E. (2010). Boundary object use in cross-cultural software development teams. Human Relations, 63(8), 1199-1221.

http://dx.doi.org/10.1177/0018726709355657

Barrett, M., Oborn, E., Orlikowski, W. J., \& Yates, J. (2012). Reconfiguring boundary relations: Robotic innovations in pharmacy work. Organization Science, 23(5), 14481466. http://dx.doi.org/10.2307/23252317

Deterding, S., Dixon, D., Khaled, R., \& Nacke, L. (2011). From game design elements to gamefulness: defining gamification. In Proceedings of the 15th International Academic MindTrek Conference: Envisioning Future Media Environments (pp. 9-15). ACM. http://dx.doi.org/10.1145/2181037.2181040

Ellison, N. B. (2007). Social network sites: Definition, history, and scholarship. Journal of Computer-Mediated Communication, 13(1), 210-230.

http://dx.doi.org/10.1111/j.1083-6101.2007.00393.x

Feldman, M. S. (2000). Organizational routines as a source of continuous change. Organization science, 11(6), 611-629. http://dx.doi.org/10.1287/orsc.11.6.611.12529

Feldman, M. S., \& Pentland, B. T. (2003). Reconceptualizing organizational routines as a source of flexibility and change. Administrative Science Quarterly, 48(1), 94-118. http://dx.doi.org/10.2307/3556620

Gal, U., Lyytinen, K., \& Yoo, Y. (2008). The dynamics of IT boundary objects, information infrastructures, and organisational identities: the introduction of 3D modelling technologies into the architecture, engineering, and construction industry. European Journal of Information Systems, 17(3), 290-304. http://dx.doi.org/10.1057/ejis.2008.13

Kellogg, K. C., Orlikowski, W. J., \& Yates, J. (2006). Life in the trading zone: Structuring coordination across boundaries in postbureaucratic organizations. Organization Science, 17(1), 22-44. http://dx.doi.org/10.1287/orsc.1050.0157

Khatib, F., Cooper, S., Tyka, M. D., Xu, K., Makedon, I., Popović, Z., \& Players, F. (2011). Algorithm discovery by protein folding game players. Proceedings of the National Academy of Sciences, 108(47), 18949-18953. http://dx.doi.org/10.1073/pnas.1115898108

Levina, N., \& Vaast, E. (2008). Innovating or doing as told? Status differences and overlapping boundaries in offshore collaboration. Mis Quarterly, 32(2), 307-332. http://dx.doi.org/10.2139/ssrn.1136880

Lindqvist, J., Cranshaw, J., Wiese, J., Hong, J., \& Zimmerman, J. (2011). I'm the mayor of my house: examining why people use foursquare-a social-driven location sharing application. In Proceedings of the SIGCHI Conference on Human Factors in Computing Systems (pp. 2409-2418). ACM. http://dx.doi.org/10.1145/1978942.1979295

March, J. G., \& Simon, H. A. (1958). Organizations. Wiley. 
Noulas, A., Scellato, S., Mascolo, C., \& Pontil, M. (2011). An Empirical Study of Geographic User Activity Patterns in Foursquare. ICWSM, 11, 70-573.

Panourgias, N. S., Nandhakumar, J., \& Scarbrough, H. (2013). Entanglements of creative agency and digital technology: a sociomaterial study of computer game development. Technological Forecasting and Social Change. http://dx.doi.org/10.1016/j.techfore.2013.03.010

Parmigiani, A., \& Howard-Grenville, J. (2011). Routines revisited: Exploring the capabilities and practice perspectives. The Academy of Management Annals, 5(1), 413453. http://dx.doi.org/10.5465/19416520.2011.589143

Rerup, C., \& Feldman, M. S. (2011). Routines as a source of change in organizational schemata: The role of trial-and-error learning. Academy of Management Journal, 54(3), 577-610. http://dx.doi.org/10.5465/AMJ.2011.61968107

Riemer, K., Overfeld, P., Scifleet, P., \& Richter, A. (2012). Eliciting the anatomy of technology appropriation processes: a case study in enterprise social media. ECIS 2012 Proceedings. Paper 134.

Skeels, M. M., \& Grudin, J. (2009). When social networks cross boundaries: a case study of workplace use of facebook and linkedin. In Proceedings of the ACM 2009 international conference on Supporting group work (pp. 95-104). ACM. http://dx.doi.org/10.1145/1531674.1531689

Thom, J., Millen, D., \& DiMicco, J. (2012). Removing gamification from an enterprise sns. In Proceedings of the ACM 2012 conference on Computer Supported Cooperative Work (pp. 1067-1070). ACM. http://dx.doi.org/10.1145/2145204.2145362

Turner, S. F., \& Rindova, V. (2012). A balancing act: How organizations pursue consistency in routine functioning in the face of ongoing change. Organization Science, 23(1), 24-46. http://dx.doi.org/10.2307/41429016

Werbach, K., \& Hunter, D. (2012). For the Win: How Game Thinking Can Revolutionize Your Business. Wharton Digital Press.

Zbaracki, M. J., \& Bergen, M. (2010). When truces collapse: A longitudinal study of price-adjustment routines. Organization Science, 21(5), 955-972.

http://dx.doi.org/10.1287/orsc.1090.0513

Zichermann, G., \& Cunningham, C. (2011). Gamification by Design: Implementing game mechanics in web and mobile apps. O'Reilly Media, Inc. 